\title{
HSD17B1 Gene
}

National Cancer Institute

\section{Source}

National Cancer Institute. HSD17B1 Gene. NCI Thesaurus. Code C104035.

This gene is involved in estrogen biosynthesis. 